\title{
Análise morfológica das aglomerações residenciais horizontais intramuros na Região Metropolitana de Campinas
}

\author{
Geise Pasquotto, Ricardo Silva, Ariane Lima, Luiz Argentone, Matheus Silva, \\ Camila Andrade, Jucilaine Peixoto, Daniela Zimmermann e Leticia Sabalo \\ Universidade Paulista, Campinas Swift - Campus II. Av. Comendador Enzo Ferrari, \\ 280 Swift 13043900 - Campinas, SP - Brasil. Email: geisebp@ gmail.com
}

Artigo revisto recebido a 11 de Dezembro de 2017

\begin{abstract}
Resumo. $O$ presente artigo objetiva analisar as aglomerações residenciais horizontais intramuros na Região Metropolitana de Campinas (RMC) inserida no Estado de São Paulo - Brasil. Por meio da lógica morfológica, o intuito é estabelecer padrões destes residenciais, bem como quantificá-los em cada um dos municípios da RMC, analisando as concentrações de cada padrão morfológico e as interações com rodovias e áreas verdes. Para tanto, num primeiro momento, é contextualizado o surgimento destas aglomerações residenciais na RMC e feita uma breve leitura legislativa sobre o tema. Em seguida, a metodologia contempla o que há de mais significativo no artigo, pois viabiliza o mapeamento de todas as aglomerações habitacionais intramuros horizontais e estabelece padrões morfológicos segundo variações de tamanho, características de construções e interferências no sistema viário e no tecido urbano. Após o mapeamento, foi possível analisar, por meio de mapas e gráficos, como é a distribuição destes padrões morfológicos e qual a relação deles com rodovias e áreas de preservação ambiental. Os resultados evidenciaram que, dentre os sete diferentes padrões de intramuros identificados, é predominante na RMC o padrão caracterizado por glebas fracionadas com a prévia intenção de se configurarem um empreendimento residencial intramuros. No que tange à relação com as vias urbanas e às áreas verdes, os mapas gerados revelaram que a maior parte destes padrões residenciais ocorre nas áreas periféricas das cidades e às margens de rodovias. Além disso, foi possível visualizar também a inevitável presença de áreas verdes protegidas nos residenciais intramuros, sendo os municípios de Campinas, Paulínia, Valinhos e Vinhedo os maiores exemplares desta relação.

Palavras-chave: Região Metropolitana de Campinas, loteamentos fechados, condomínios fechados, forma urbana, padrões urbanos
\end{abstract}

\section{Introdução}

A Região Metropolitana de Campinas, criada pela Lei Complementar Estadual n. 870 no ano 2000, é composta, atualmente, por 20 municípios, ocupa uma área de 3.791,82 $\mathrm{km}^{2}$, correspondente a $1,47 \%$ do território paulista (AGEMCAMP, 2006; IBGE, 2010), e possui população estimada de 3.043.217 habitantes (IBGE, 2014). A consolidação desta região aconteceu no período entre as décadas de 1970 a 1990, quando a interiorização da indústria no Estado de São Paulo permitiu o estabelecimento de uma associação entre a parte socioeconômica do interior e a região metropolitana da capital paulista (Baeninger, 2001; Gonçalves Junior e Côrrea, 2011). A partir de então, o dinamismo econômico e populacional foi marcado por intensos deslocamentos 
populacionais migratórios da Região Metropolitana de São Paulo (RMSP) no sentido interior do Estado, mobilizando aproximadamente 500.000 pessoas para Campinas e municípios vizinhos, os quais se destacaram no processo de urbanização decorrente desse fluxo espacial (Baeninger, 2001).

A malha rodoviária local representou um importante fator para essa expansão, principalmente por meio das rodovias Anhanguera (SP-330), Bandeirantes (SP348), Dom Pedro (SP-065), Santos Dumont (SP-075), Adhemar de Barros (SP-340) e Jorn. Francisco Aguirre Proença (SP-101), as quais ligam a RMC à Região Metropolitana de São Paulo e ao interior do Brasil. Tal localização estratégica contribuiu com a sobrepujante influência do município de Campinas para além da região metropolitana, por uma rede urbana densa e articulada de relações comerciais, de trabalho, moradia e de infraestrutura urbana, com grande facilidade de acessos, curtas distâncias e sistema viário fisicamente bem estruturado (AGEMCAMP, 2006).

Durante o período de expansão da malha rodoviária local pertencente ao município de Campinas e região, em especial a partir da década de 1990, começou a ser observado um novo padrão de urbanização periférica no território urbano da RMC em forma de conglomerados residenciais intramuros, com população composta, predominantemente, por habitantes de média e alta renda, e cuja ocorrência acontecia fora da malha urbana consolidada. Buscava-se nas áreas afastadas uma estrutura rodoviária com melhor acesso para facilitar a locomoção de âmbito intermetropolitano, além de melhores condições de convívio e bem-estar junto a áreas verdes, aliado ao afastamento da violência urbana acentuada, cada vez mais frequente nesses municípios (Freitas, 2008).

Reis (2006) esclarece que a dispersão desses conglomerados ocorreu predominantemente pelo espraiamento dos locais de trabalho e pela facilidade do deslocamento metropolitano diário por meio da malha viária local. Além disso, o autor menciona que um dos atrativos para o deslocamento dessa população foi a oferta de imóveis com menor custo ou incentivos fiscais que contribuíssem para a instalação deles na periferia de tais municípios. Melgaço (2012), por sua vez, analisa os impactos destes empreendimentos no território metropolitano e a relação conflituosa entre as aglomerações residenciais horizontais intramuros $\mathrm{e} o$ espaço urbano, quanto aos critérios para a escolha do terreno a ser implantado um residencial murado: 'Eles devem estar suficientemente afastados dos espaços urbanos para que seus moradores possam usufruir de áreas verdes, do contato com a natureza e da calma, silêncio e tranquilidade proporcionados pelo distanciamento dos locais de maior trânsito de veículos. Por outro lado, eles devem estar suficientemente próximos para que possam utilizar-se das facilidades oferecidas pelos centros urbanos' (Melgaço, 2012, p. 10).

Foi a partir da década de 1980 , então, que a expansão urbana e a valorização imobiliária encorajaram o crescimento desmedido dos bairros fechados (Silva, 2008). Num primeiro momento, estabeleceram-se como condomínios edilícios horizontais, com casas padronizadas, divisão de propriedade por fração ideal e baixa densidade. A partir dos anos 1990, os bairros fechados se manifestaram como loteamentos convencionais, fechados, com construção individualizada das casas, divisão de propriedade por lotes maiores, e densidade superior ao dos condomínios edilícios horizontais. Ambos regulamentados pela Lei Federal 4591/65, no qual os lotes devem ter área mínima de $125 \mathrm{~m}^{2}$ e frente mínima de 5 $\mathrm{m}$, com índices urbanísticos de uso e ocupação do solo definidos perante a legislação municipal em vigor, e densidade líquida média superior à 100 hab/ha. Posteriormente, estes loteamentos convencionais fechados também ganharam espaço na zona rural (Freitas, 2008), por meio de sucessivas combinações legislativas federais e municipais, tecendo complexos conjuntos habitacionais de formas diversas e em detrimento da própria legitimidade (Figura 1).

Os condomínios edilícios, garantidos pela Lei Federal 4591/65, definem-se por uma área de gleba planejada e edificada de forma privativa, com o intuito de ser fechada (Silva, 2008). Já os loteamentos fechados, 


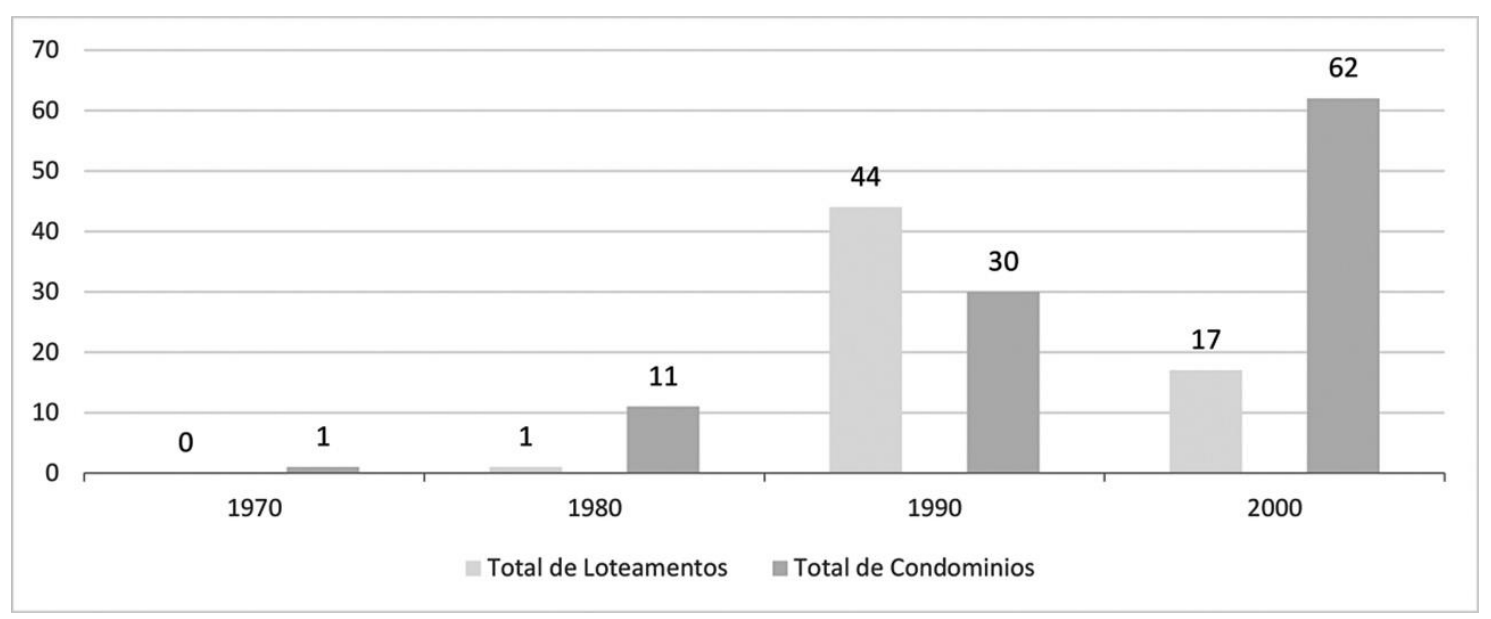

Figura 1. Comparativo dos protocolos e aprovações de loteamentos fechados e condomínios horizontais fechados no município de Campinas, ao longo das décadas (fonte: Autores com base em Silva, 2008).

compostos por loteamentos convencionais que são abertos por princípio, estão previstos na Lei Federal 6766/79 e são entendidos como a subdivisão de gleba em lotes destinados à edificação, com abertura, prolongamento ou modificação de vias de circulação. Eles são fechados posteriormente, por meio de decretos municipais, com muros e guaritas que restringem o acesso público. Ao contrário dos condomínios edilícios, que possuem uma área máxima de lote ou gleba a ser edificada que varia entre $10.000 \mathrm{~m}^{2}$ e $40.000 \mathrm{~m}^{2}$, de acordo com o zoneamento, estipulada conforme lei municipal, os loteamentos fechados interferem no desenho urbano pelo fato de não possuírem leis regulamentadoras de tamanho de área a ser loteada.

Não obstante, os loteamentos fechados são compostos por lotes e providos de infraestrutura pública básica; os condomínios, por outro lado, são privados desde sua concepção, constituídos por unidades habitacionais acrescidas de infraestrutura e sistema de lazer prontos, que são distribuídos em frações ideais a seus condôminos. As áreas comuns dos loteamentos fechados são públicas e cedidas à Associação dos Proprietários quando houver regulamentação municipal estabelecida para o fechamento do conjunto; a conservação e manutenção das áreas comuns são de responsabilidade do município, mas também podem ser transmitidas à Associação, conforme legislação municipal. Nos condomínios, as áreas comuns são particulares e adquiridas juntamente com as unidades habitacionais; a conservação e manutenção são, portanto, de responsabilidade privada, custeada pelos condôminos. No condomínio, os impostos pagos são referentes à unidade habitacional e à fração ideal das áreas comuns; no loteamento fechado, os impostos referem-se apenas aos lotes. Em ambos os conjuntos habitacionais, ou seja, tanto nos loteamentos quanto nos condomínios horizontais fechados, o acesso é controlado por guarita, no condomínio por ser privado por natureza, no loteamento fechado por meio de regulamentação municipal.

Tal embasamento jurídico tem por objetivo a busca pela compreensão legítima destas modalidades habitacionais. $\mathrm{Na}$ sequência, o estudo dos padrões da forma urbana indica os principais mecanismos utilizados neste artigo para se compreender o estabelecimento dos conjuntos residenciais intramuros na Região Metropolitana de Campinas.

\section{Materiais e métodos}

A morfologia urbana, segundo Lamas (1992), é utilizada para designar o estudo da configuração e da estrutura exterior de um objeto, buscando entender as formas por 
meio dos fenômenos que lhe deram origem. $\mathrm{O}$ autor acredita que são necessários instrumentos de leitura que permitam organizar e estruturar o conhecimento do meio urbano. Para tanto, a breve contextualização da consolidação da RMC permite entender como e por que as aglomerações intramuros tomaram forma e se estabeleceram na região. Neste caso, entende-se que os polos socioeconômicos, a estrutura rodoviária e as manobras do parcelamento, uso e ocupação do solo foram os fatores primários de configuração destes conjuntos residenciais.

Após a compreensão da forma, o estudo dos tipos permite assimilar os padrões urbanos e arquitetônicos que são habitualmente produzidos num determinado contexto (Vaz, 1994). Além disso, o estudo dos tipos também pode abranger uma concepção teórica que reúne em si as características elementares de um componente morfológico no espaço urbano (Correia, 2001). Neste sentido, o tipo é analisado, categorizado e sistematizado por meio da tipologia, com base na passagem do tempo histórico e suas transformações culturais (Panerai, 2006).

Perante este entendimento, o presente artigo objetiva analisar e estabelecer padrões de aglomerações residenciais intramuros nas cidades da RMC, buscando compreender as variações destes elementos urbanos, suas hierarquias, sua interferência na produção do espaço urbano e sua relação com o contexto morfológico em cada um destes municípios.

Como este trabalho nasceu com o objetivo primário de localizar e identificar todas as aglomerações residenciais horizontais intramuros dentro da região de Campinas, o estímulo inicial para a produção desta pesquisa mais complexa ocorreu quando percebeu-se uma significativa imprecisão nas definições dos mencionados produtos arquitetônicos. Após ampla coleta de dados junto às prefeituras, imobiliárias e imagens de satélite, notou-se que os termos legais a respeito destas aglomerações residenciais eram desconhecidos por parte das próprias administrações públicas e do mercado imobiliário.

Tais inconsistências encorajaram a criação de um parâmetro próprio de qualificação e identificação dos conjuntos residenciais conforme características particulares de cada um, pois embora a legislação federal esteja vigente e exija o seu cumprimento, a realidade mostra práticas muito distintas da aplicação destas normas que, combinadas às normas municipais, produzem aglomerações residenciais intramuros das mais variadas formas.

Sendo assim, para tecer as análises sobre o padrão das aglomerações horizontais intramuros na RMC e atingir os novos objetivos estipulados nesta pesquisa, definiuse duas estratégias de estudo: inicialmente fez-se um mapeamento de todas as aglomerações horizontais intramuros nas cidades da região metropolitana por meio da ferramenta Google Maps; em seguida, buscou-se por padrões tipológicos e, destes, foram identificadas variações procedentes de tamanho, de intervenções ao sistema viário e padrões de construções habitacionais. Neste sentido, a análise tipológica destas aglomerações habitacionais ocorreu de maneira quantitativa, uma vez que foram levantados todos os exemplares intramuros das cidades da região metropolitana e caracterizados segundo padrões de distribuição dos tipos no território.

O produto gerado foi uma classificação da forma urbana das aglomerações intramuros composta por sete padrões, cada qual ilustrada com um exemplar morfológico extraído da malha urbana e representado por um modelo desenhado em vetor. Para organizar os dados de tal pesquisa, criou-se também uma tabela para dividir e quantificar cada padrão encontrado no território de cada município, sendo possível identificar a predominância de cada um nos vinte municípios da RMC.

$\mathrm{Na}$ sequência, os diferentes padrões foram alocados no mapa da região metropolitana permitindo uma macrovisualização da concentração destas diferentes aglomerações habitacionais intramuros nas cidades da região. Esta estratégia de pesquisa permitiu, por fim, a compilação de análises pontuais e comparativas das cidades pertencentes à RMC quanto aos padrões, às características e às interferências que os residenciais intramuros nelas representam. 
Classificação da forma urbana das aglomerações intramuros

A fim de estabelecer um padrão tipológico de aglomerações horizontais intramuros que pudessem se inter-relacionar, seja pelo tamanho e características das habitações, além do possível impacto que podem acarretar no sistema viário e/ou entorno, a classificação da forma urbana das aglomerações intramuros estabeleceu parâmetros de identificação dessas moradias e auxiliou na obtenção de análises coesas do perfil de implantação desses empreendimentos a partir de mapeamentos nos municípios da RMC.

\section{Padrão 1}

Caracteriza-se por glebas fracionadas de tal modo que fica evidente a intenção de se tornar uma aglomeração residencial intramuros, pois aloca os terrenos ordenadamente desconsiderando a forma predominante na cidade. As construções habitacionais são independentes e heterogêneas, em lotes que variam em média de 220 a $280 \mathrm{~m}^{2}$, com densidade líquida média estimada de 140 hab/ha (Figura 2).

\section{Padrão 2}

São aglomerações residenciais intramuros de grande porte, que se confundem com a dimensão de bairro e seguem a forma da cidade. As construções habitacionais são independentes e heterogêneas, com lotes que variam em média de 125 a $1000 \mathrm{~m}^{2}$, sendo os maiores, geralmente, consequência da unificação de dois ou mais lotes menores, e densidade líquida média variável de 70 a 280 hab/ha (Figura 3).

\section{Padrão 3}

Constitui-se por intramuros linear, com poucas ou apenas uma rua, desenhado para alocar os terrenos ordenadamente, e não segue a forma predominante na cidade. As construções habitacionais são independentes e heterogêneas, com lotes que variam em média de 220 a $600 \mathrm{~m}^{2}$, com densidade líquida média variável de 35 a 240 hab/ha (Figura 4).

\section{Padrão 4}

Empreendimentos de pequeno e médio porte, que não interferem no viário da cidade, entregues com infraestrutura completa e construções habitacionais padronizadas. Legitimados pela Lei Federal 4591/64 a qual prevê normas para constituição de condomínios horizontais fechados, com lotes que variam em média de 150 a $450 \mathrm{~m}^{2}$, e densidade líquida média de 60 a 240 hab/ha (Figura 5).

\section{Padrão 5}

Trata-se de terreno que foi notadamente desenhado para ser intramuros, e acontece de modo a não alterar o traçado viário da cidade, não seguindo, porém, a forma predominante na cidade. As construções habitacionais são independentes e heterogêneas, com lotes que variam em média de 220 a $350 \mathrm{~m}^{2}$, e densidade líquida média de 116 a 160 hab/ha (Figura 6).

\section{Padrão 6}

Caracteriza-se por intramuros provenientes de parte urbana já consolidada da cidade. As construções habitacionais são, portanto, independentes e heterogêneas, pois provavelmente já existiam antes do fechamento desta parcela urbana, com lotes que variam de 300 a $500 \mathrm{~m}^{2}$ e densidade líquida média de 70 a 140 hab/ha (Figura 7).

\section{Padrão 7}

Empreendimentos de grande porte, que interferem no viário da cidade. São entregues com infraestrutura completa e construções habitacionais padronizadas, com lotes que variam de 120 a $300 \mathrm{~m}^{2}$, e densidade líquida média de 116 a 280 hab/ha (Figura 8). 


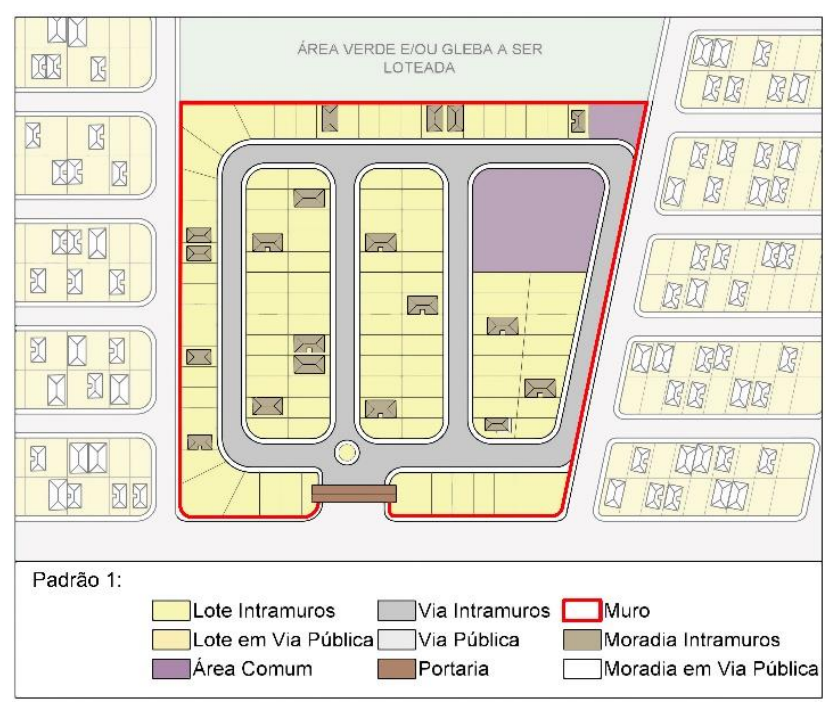

Figura 2. Esquema Padrão 1

(fonte: Autores, com base em imagem satélite do Google Earth, 2015)

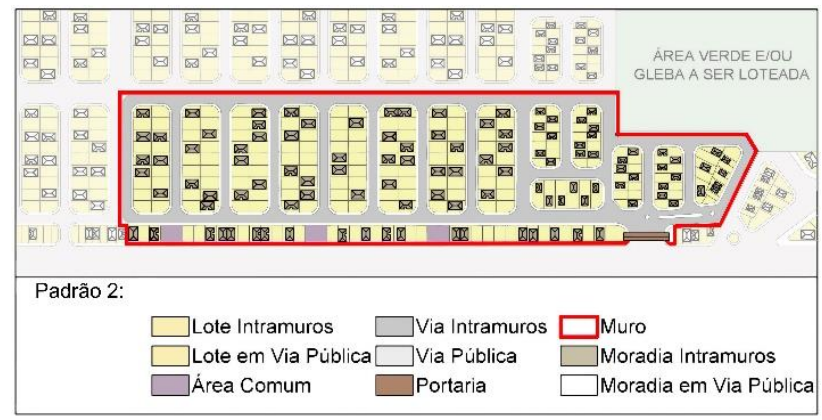

Figura 3. Esquema Padrão 2

(fonte: Autores, com base em imagem satélite do Google Earth, 2015).

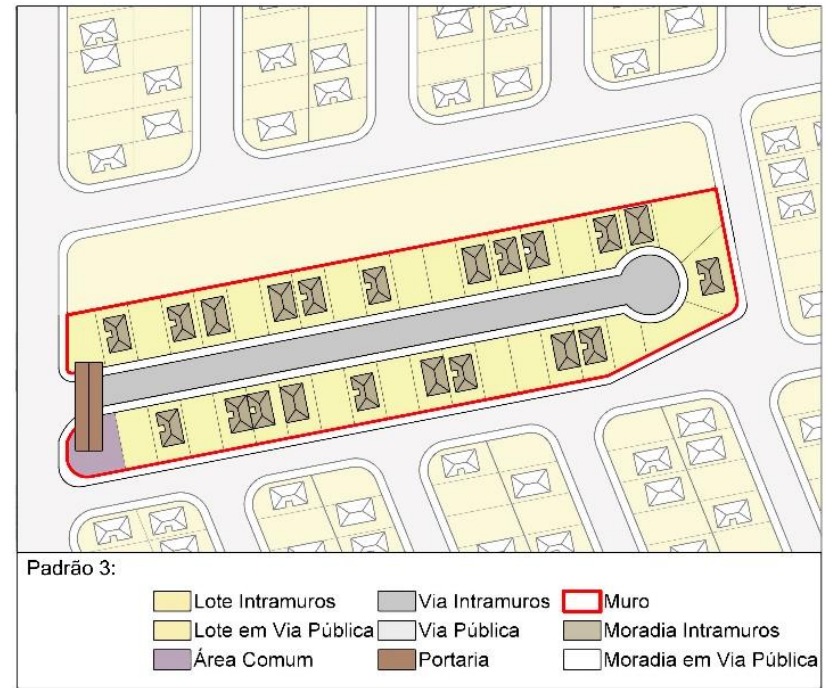

Figura 4. Esquema Padrão 3

(fonte: Autores, com base em imagem satélite do Google Earth, 2015). 


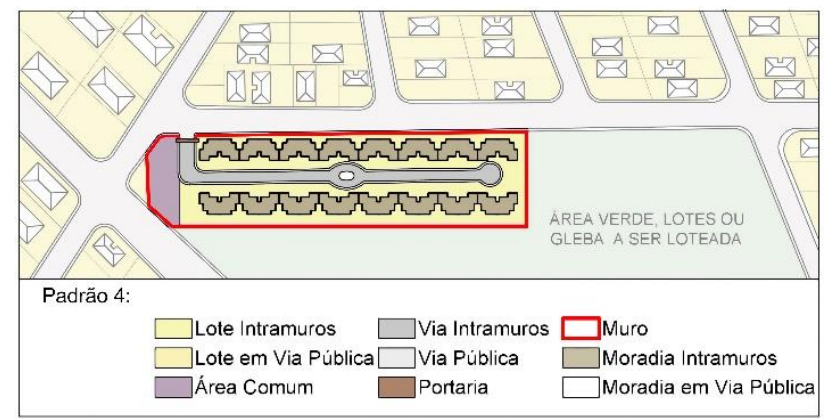

Figura 5. Esquema Padrão 4

(fonte: Autores, com base em imagem satélite do Google Earth, 2015).

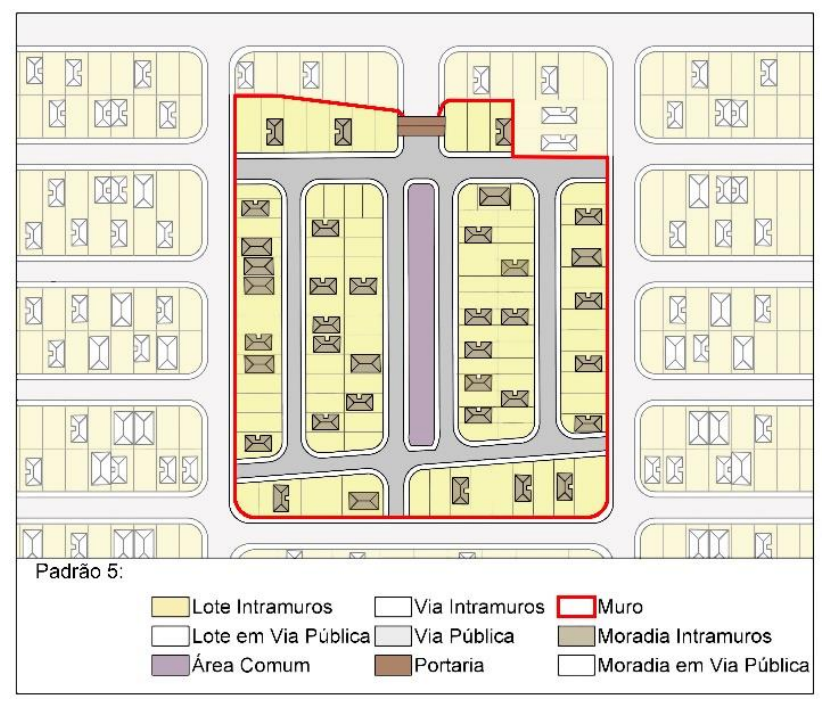

Figura 6. Esquema Padrão

(fonte: Autores, com base em imagem satélite do Google Earth, 2015.

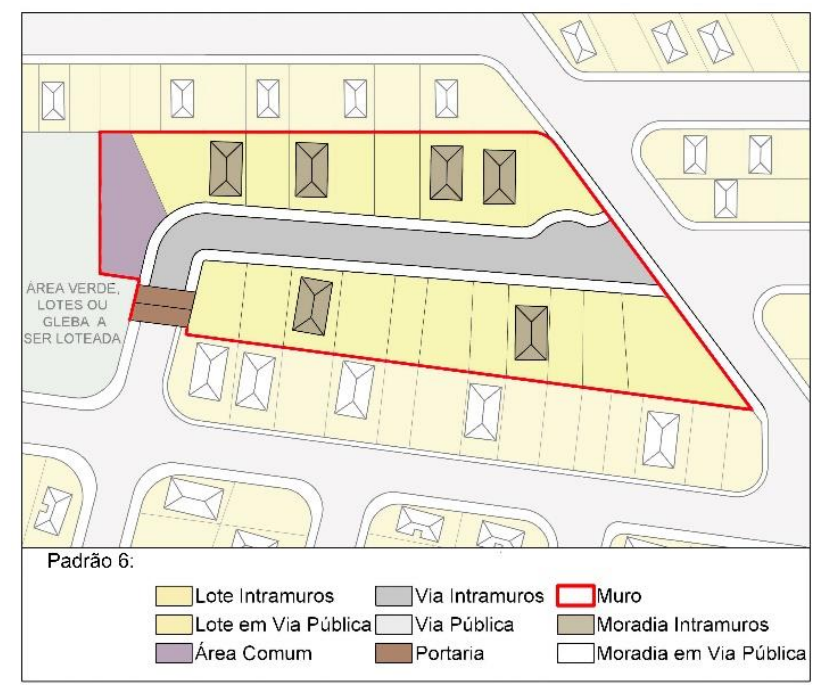

Figura 7. Esquema Padrão 6

(fonte: Autores, com base em imagem satélite do Google Earth, 2015). 


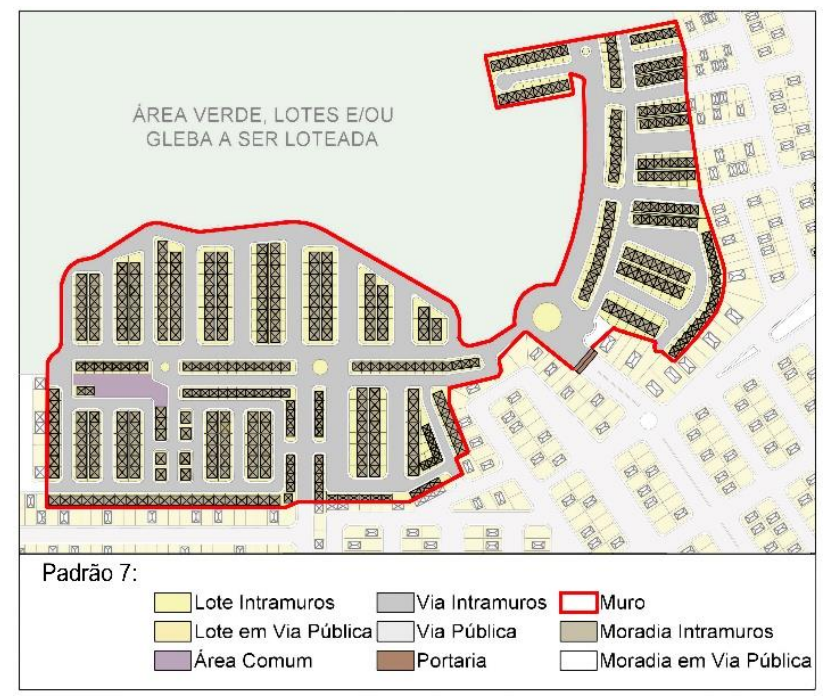

Figura 8. Esquema Padrão 7

(fonte: Autores, com base em imagem satélite do Google Earth, 2015).

\section{Tabela mestra de padrões e análises}

Uma vez que os padrões formais dos intramuros horizontais foram definidos, a próxima etapa constituiu-se em analisar a concentração de cada um nas cidades da RMC. Para tanto, foi criada uma tabela mestra de padrões, na qual cada um dos intramuros identificados nas vinte cidades da região metropolitana foi sendo alocado conforme padrões da forma urbana prédefinidos. Esta etapa metodológica permitiu observar qual padrão predomina na RMC e em qual município, e qual deles tem mais ou menos ocorrências, direcionando o estudo para uma fase analítica mais pontual.

A Figura 9 resume a tabela mestra de padrões e traz uma visão geral da concentração de cada padrão formal nas cidades da RMC. O Padrão 1 predomina com 125 exemplares, representando $32 \%$ de todos os padrões da forma urbana encontrados na região metropolitana. Os padrões 2 e 4 vêm em seguida, com $22 \%$ e $19 \%$, respectivamente, e o que menos se manifesta na área estudada é o padrão 6 , com apenas 16 exemplares, representando $4 \%$ do total de intramuros.

Analisando os dados obtidos por meio da tabela mestra de padrões de intramuros na RMC, foi possível perceber que o Padrão 1, na qual o empreendimento já nasce com a intenção de ser intramuro sem seguir o traçado viário, predomina na cidade de Valinhos, com 24 amostras. A cidade de Campinas segue com 18, Paulínia 15 casos, Itatiba, Americana e Itatiba com 8 e Vinhedo com 7. A cidade de Pedreira foi a única que não apresentou nenhum exemplar deste padrão.

Com relação ao Padrão 2, em que os intramuros possuem dimensões equivalentes ou superiores à escala do bairro, e seguem a morfologia da cidade, Campinas é a cidade que mais abriga exemplares, com 22 deles, seguido de Valinhos com 16, Vinhedo com 13 e Indaiatuba com 10. Os municípios de Americana, Arthur Nogueira, Cosmópolis, Hortolândia, Morungaba, Nova Odessa, Santa Bárbara d'Oeste e Sumaré, sendo eles quase metade dos municípios da RMC, não apresentaram casos deste padrão.

O Padrão 3, com intramuros dispostos linearmente em torno de uma rua, sem acompanhar a forma da cidade, assim como o Padrão 1, tem como maior representante a cidade de Valinhos, com 18 exemplares, seguido de Campinas com apenas $4 \mathrm{e}$ Paulínia com 2. O restante dos municípios, ou possuem apenas 1 caso deste padrão, ou nenhum.

Os Padrões 4 e 7, embora similares no que diz respeito aos empreendimentos completos e com habitações padronizadas, se 


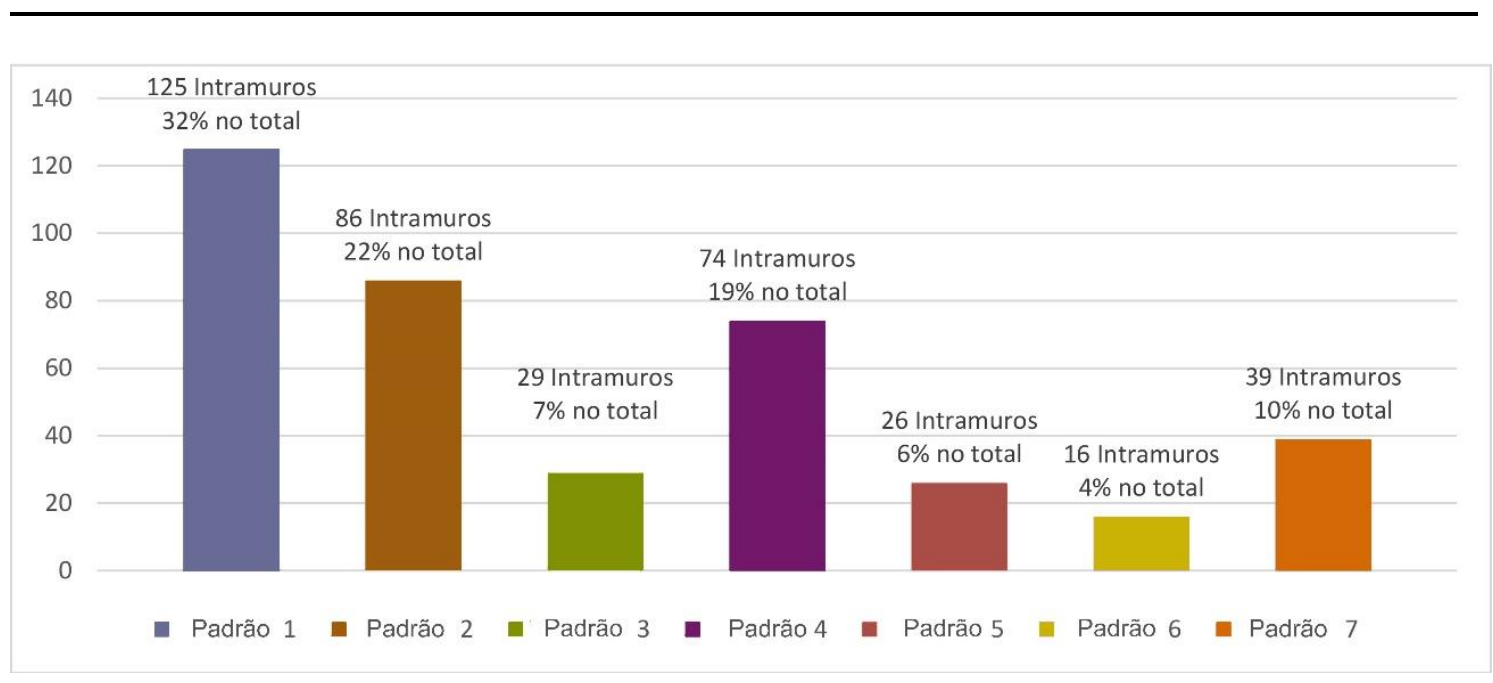

Figura 9. Concentração de padrões nas cidades da RMC.

diferenciam apenas pela sua interferência no sistema viário municipal. A 4 não interfere no viário urbano e a 7 , ao contrário, interfere. Ambos os padrões são predominantes na cidade de Campinas, a 4 com 43 exemplares no município e a 7 com 30 . O Padrão 4 ainda possui 10 exemplares no município de Indaiatuba, 7 exemplares em Valinhos e três em Hortolândia e em Jaguariúna; 10 são os municípios que não possuem nenhum caso deste tipo. Já o Padrão 7 tem ainda menos exemplares além de Campinas, com apenas 2 em Hortolândia, Jaguariúna e Sumaré e 1 em Indaiatuba, Paulínia e em Pedreira.

Os Padrões 5 e 6, embora bastante distintos entre si, são as que menos possuem exemplares na RMC. O Padrão 5, com terrenos que foram projetados para serem intramuros, que não seguem a forma da cidade e que, contudo, não interferem no viário urbano, possui maior número de exemplares no município de Valinhos, com 10, e em Campinas, com 8, mas ao todo são 26 casos em toda a região metropolitana. $\mathrm{O}$ Padrão 6, por sua vez, contabiliza 16 casos, sendo 9 em Valinhos e 2 em Americana, em Campinas e em Vinhedo.

A Figura 10 ilustra a completa divisão dos aglomerados residenciais murados em todos os municípios da Região Metropolitana de Campinas.

Analisando de maneira quantitativa, o Padrão 1 é o modelo de intramuros que mais está distribuído nas cidades da RMC, o que evidencia a tendência regional de se fazer loteamentos com a premissa de torná-los fechados, mesmo em municípios que não possuem leis que evidenciam esta permissão, bem como Arthur Nogueira, Monte Mor, Pedreira, Sumaré e Vinhedo. O Padrão 4, por sua vez, é o que mais apresenta exemplares concentrados em um único município: Campinas.

A imagem que segue exemplifica a concentração deste padrão na região do Taquaral no município (Figura11).

Uma última análise proveniente da tabela mestra de padrões pode ser feita pela comparação da soma de área dos intramuros de cada cidade com as respectivas áreas urbanas municipais, pois, por meio desta verificação é possível observar, de fato, o que a quantidade de intramuros representa em proporção para cada um dos municípios da RMC. Tendo isto em vista, os levantamentos gráficos evidenciaram que a cidade de Vinhedo apresenta a maior porção do seu território urbano ocupado por intramuros, os quais representam quase 29,8 $\%$ desta categoria residencial no município. Em seguida, embora com uma significativa queda percentual, é observada a cidade de Valinhos alcançando 20,85 \%, Jaguariúna com $17,6 \%$ e Holambra com 12,49 \%. É interessante notar que a capital da região metropolitana, ainda que lidere o ranking de quantidade de empreendimentos residenciais fechados, tem apenas 4,36 \% de sua área urbana ocupada por estas aglomerações (Figura 12). 


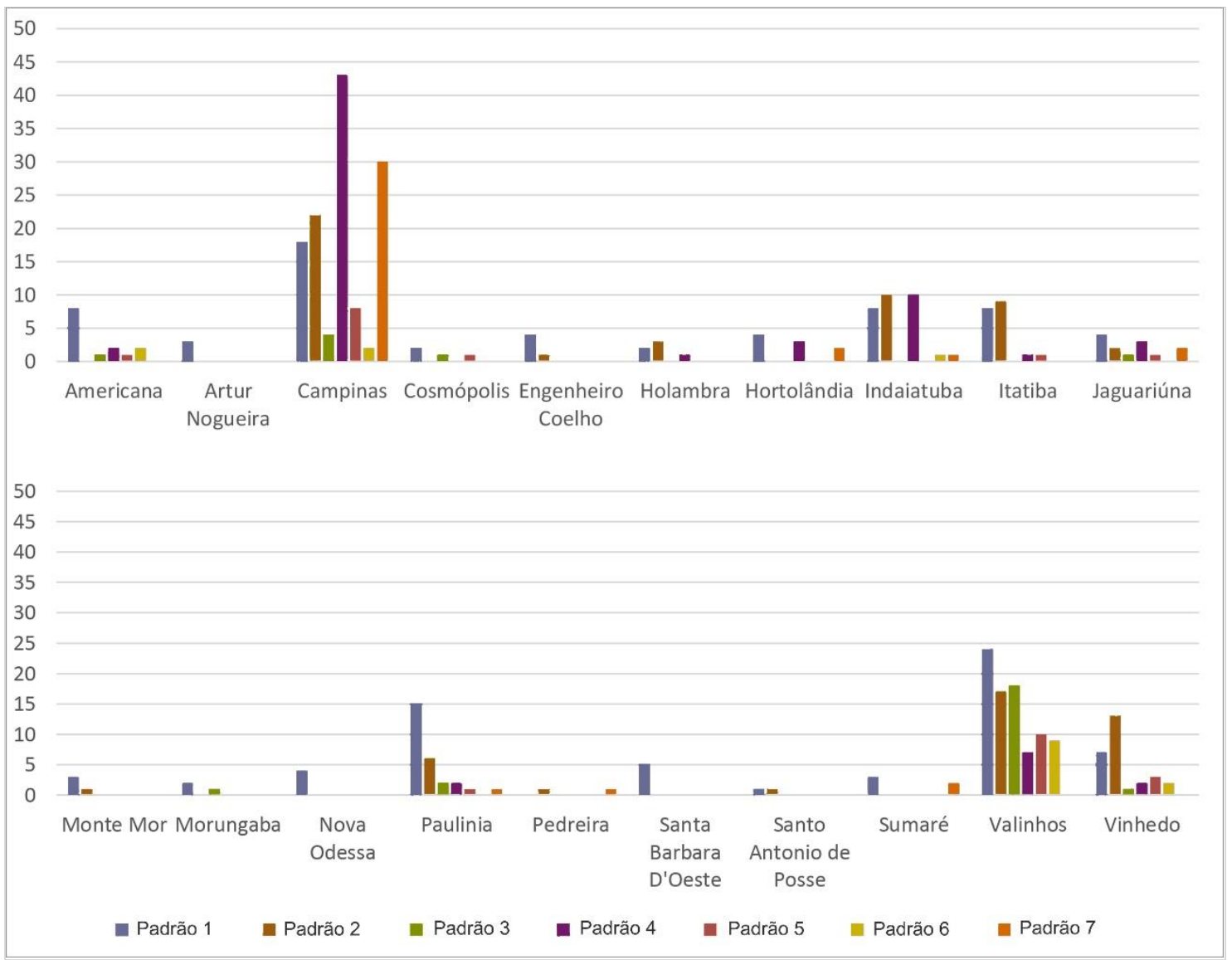

Figura 10. Padrões e quantidades de intramuros nas cidades da RMC.

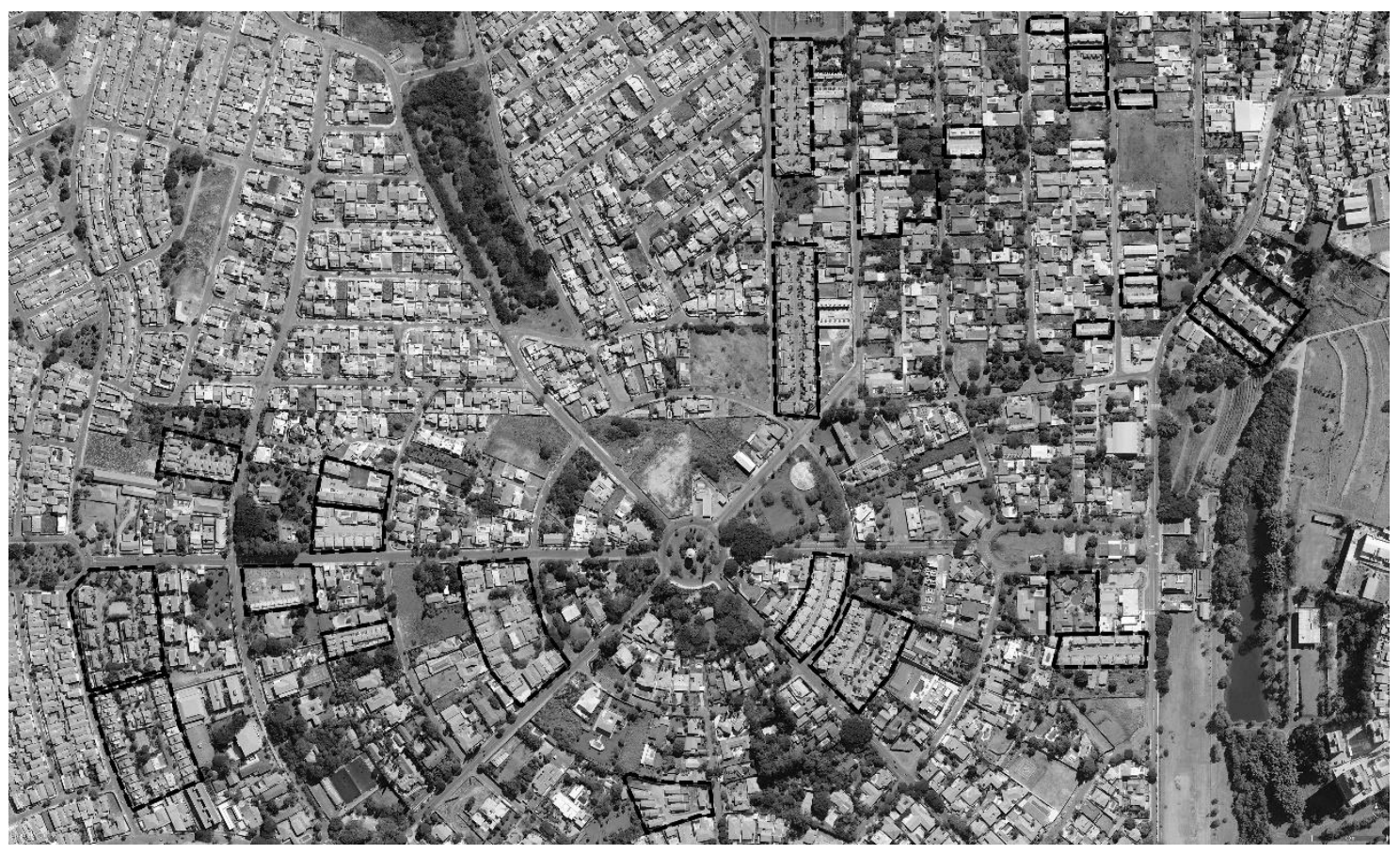

Figura 11. Vista superior da região Taquaral, no município de Campinas, com atenção à concentração de aglomerações intramuros de Padrão 4

(fonte: autores, com base em imagem satélite do Google Earth, 2015). 


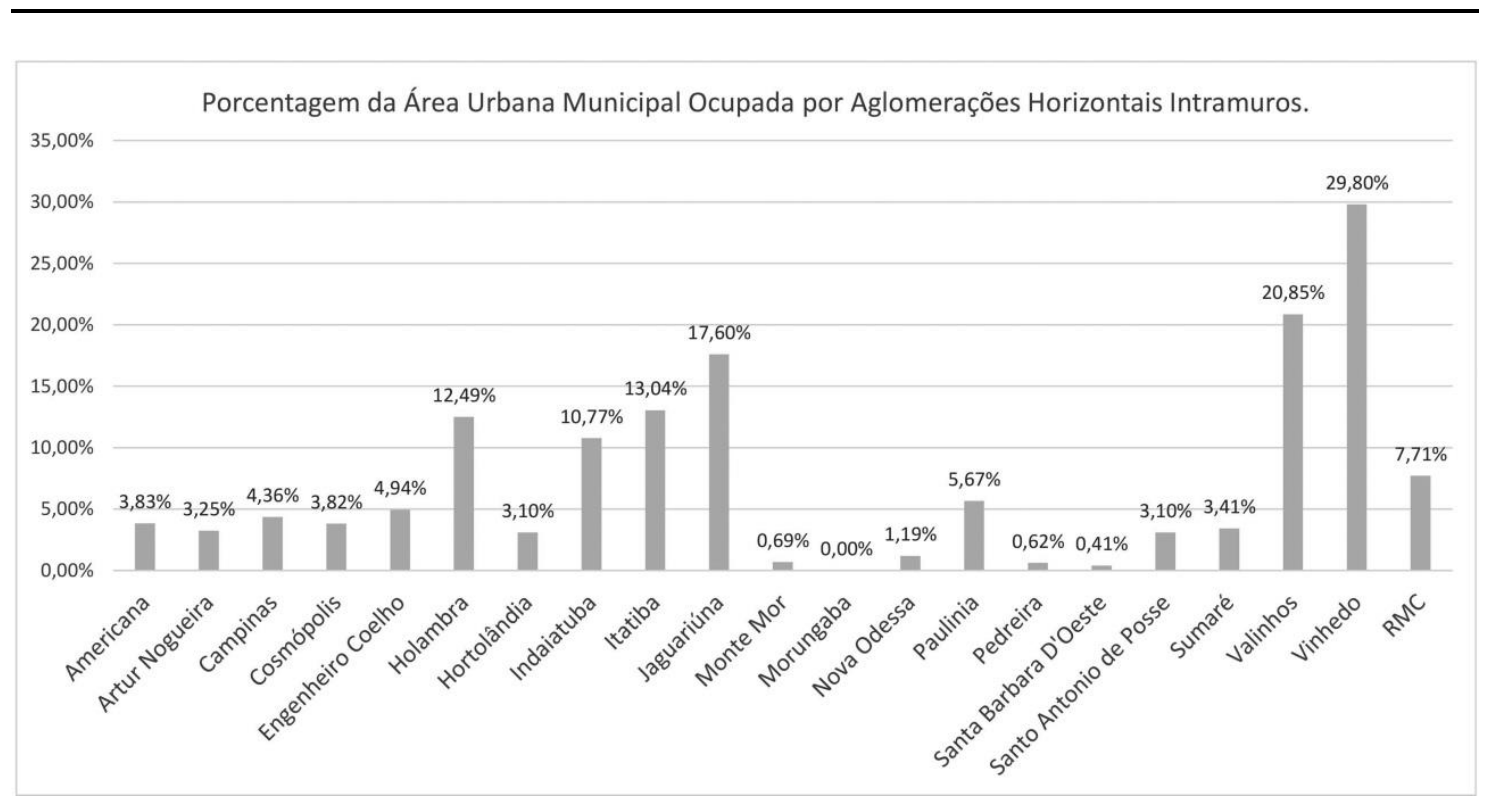

\section{Figura 12. Área dos municípios da RMC e respectivas ocupações intramuros relativas à área urbana municipal.}

\section{Mapas e análises dos padrões da forma urbana na RMC}

Uma vez apresentados dados gráficos substanciais para o entendimento da ocupação de aglomerações intramuros horizontais na RMC, os mapas e análises compilados e apresentados a seguir têm o objetivo de integrar as informações até então explanadas com fatores considerados de correspondência direta pela presença destes padrões residenciais nos municípios da região metropolitana, tais como rodovias e áreas verdes, pois estas relações denotam o efeito dessas ocupações do território metropolitano.

\section{Padrões da forma urbana e rodovias}

O primeiro fato que se observa no mapa apresentado (Figura 13) são as grandes manchas alaranjadas, correspondentes ao Padrão 2 e que, não por acaso, tratam-se dos intramuros de grande porte, que seguem a forma da cidade e têm a segunda maior ocorrência dentre os sete padrões estudados. No entanto, aparecem apenas em onze dos 20 municípios da RMC, e percebe-se que este tipo de aglomeração intramuros acontece majoritariamente nas áreas periféricas das manchas urbanas de cada cidade.

De fato, a grande maioria de todos os padrões residenciais intramuros está localizada às margens das manchas urbanas das cidades e próximas a vias arteriais, rodovias municipais e intermunicipais, o que deixa em evidência o caráter precursor destes empreendimentos, os quais nasceram com o intuito de se consolidarem longe de centros urbanos e próximos a rodovias, afastando-se da marcante violência urbana, em busca de melhores condições de bem estar junto a áreas verdes e viabilizando a locomoção através de veículos automotivos.

Analisando o mapa é possível perceber que a maior ocorrência de intramuros acontece nas regiões noroeste, central a sudeste do território metropolitano, formando uma mancha linear que segue o traçado das rodovias Anhanguera e Dom Pedro, conforme detalhe da Figura 14.

Por fim, nota-se ainda que o mapa evidencia o diagnóstico da Figura 12, que constata visualmente que os municípios de Valinhos e Vinhedo são os municípios da RMC que possuem a maior parte de seu território urbano ocupado por residenciais murados. Tal questão pode ser explicada pelo fato de esses municípios terem sido alvos de uma intensa estratégia de urbanização com ocupação em formato de loteamentos fechados. 


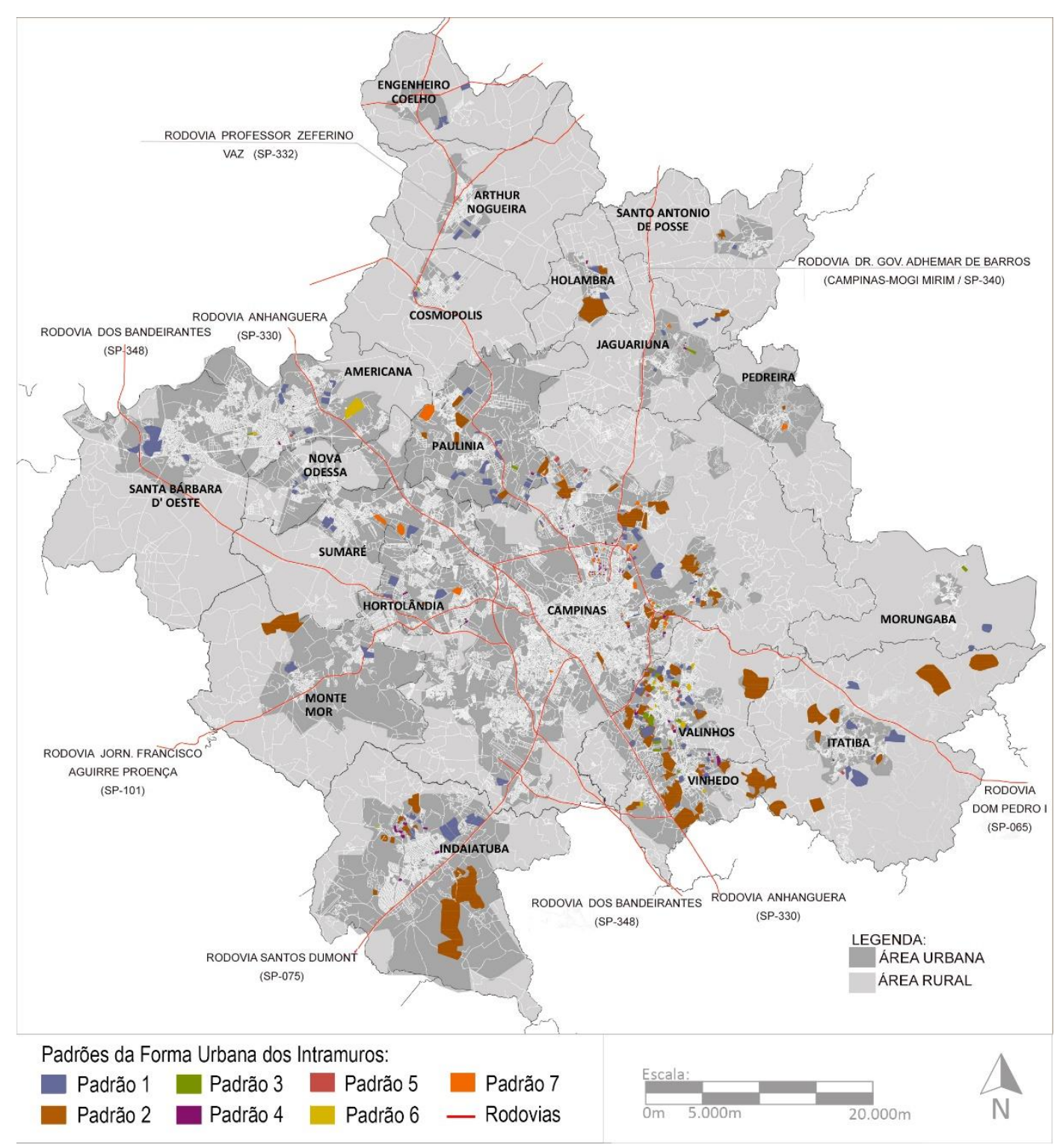

Figura 13. Mapeamento dos padrões de aglomerações intramuros na RMC.

\section{Padrões da Forma Urbana em áreas verdes protegidas}

Uma vez que as áreas verdes são premissas básicas para a implantação de empreendimentos residenciais intramuros, conforme salienta Eleusina de Freitas (2008), a preservação do estilo e qualidade de vida dos moradores dessas residências é garantida por estratégias de marketing. $\mathrm{O}$ apelo comercial apresenta as áreas verdes como um uso exclusivo para essa parcela da população, e é reforçado, ainda, pelo crescente aumento do interesse do público alvo em se afastar da criminalidade dos centros urbanos e conviver em um espaço habitável com qualidade de vida superior. Neste sentido, a valorização do verde traz o conceito de sua preservação e dos benefícios do estilo de vida de quem convive com a natureza.

Não obstante, a necessidade publicitária e o interesse mercadológico pelos ambientes naturais, levam alguns empreendedores a fazerem uso de áreas verdes protegidas para viabilizarem seus produtos (Área de Proteção Permanente / APP e Área de Proteção Ambiental / APA). As APPs são Unidades de Proteção Integral, as APAs são Unidades de Uso Sustentável, o que quer dizer que, em áreas naturais de notória fragilidade ambiental e relevante valor ecológico 


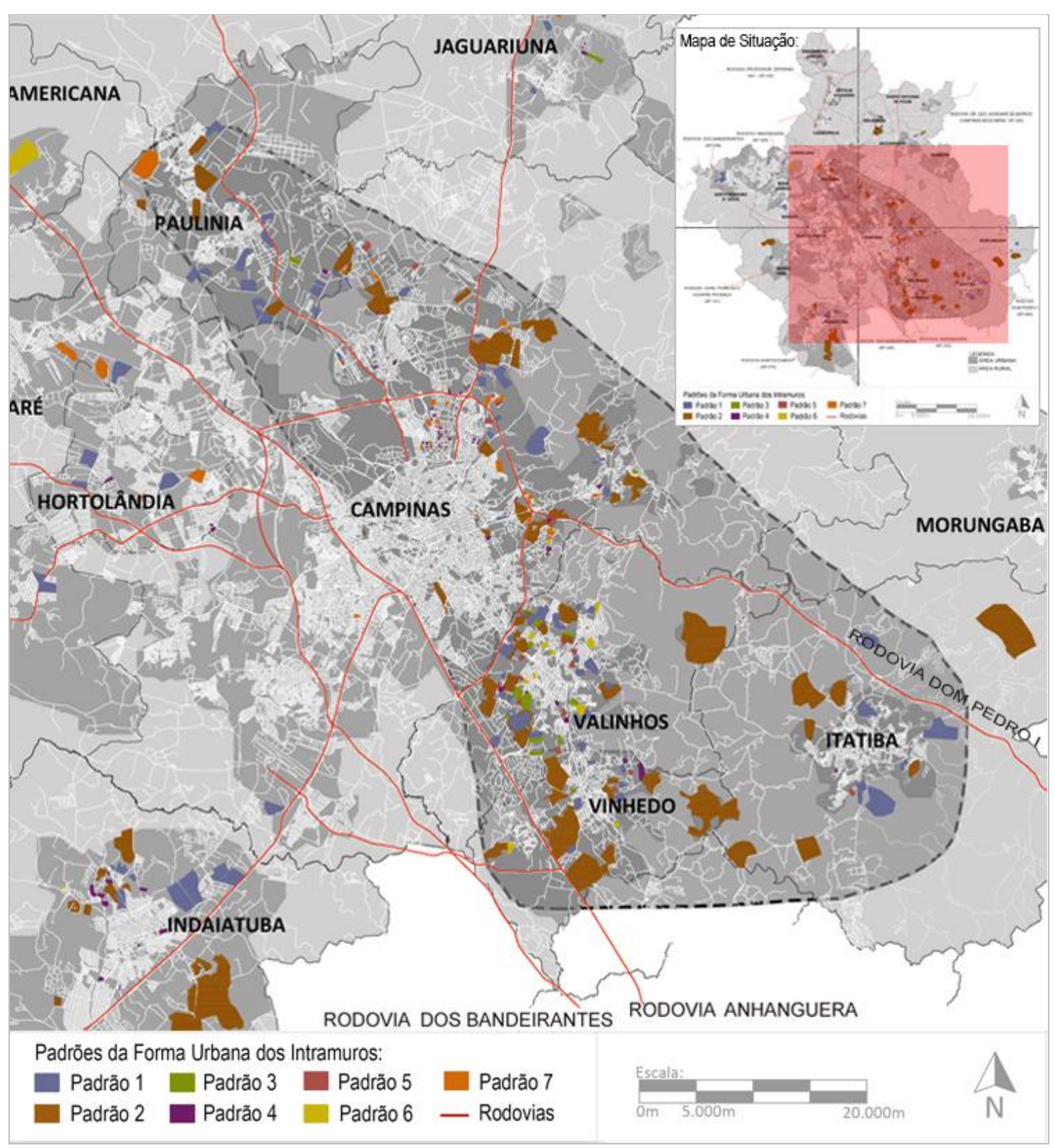

Figura 14. Detalhe para concentração de intramuros nas imediações das rodovias Dom Pedro I e Anhanguera.

estabelece-se proteção integral (APP), e em áreas naturais com relevância para o uso antrópico, o uso deve ser ao menos sustentável (APA). O conceito de proteção integral inviabiliza qualquer intervenção humana, é limitante quanto à exploração dos recursos naturais e proíbe o uso com fins econômicos; já o uso sustentável suscita o uso disciplinado dos recursos naturais, estabelecendo regras para compatibilizar a proteção da natureza com o uso consciente de seus recursos (Lei Federal 12.651/2012).

À parte das áreas verdes protegidas, compreende-se que na Lei $6.766 / 79$ os espaços livres exigidos em proporção, no ato do parcelamento do solo, são compostos por áreas verdes (estado natural) e jardins e parques (áreas verdes com tratamento urbanístico). Em seu artigo 22, a lei determina que, a partir do registro do loteamento, os espaços livres constantes no projeto e no memorial descritivo passam a 
integrar o domínio do Município. Além disso, o artigo 17 assegura que, uma vez mencionado no projeto e no memorial descritivo, os espaços livres não poderão ter sua destinação alterada pelo loteador. No entanto, quando estes espaços livres entram para a jurisdição municipal, ficam a cargo de suas regulamentações que, em alguns casos, ferem o estabelecido pela lei federal. Exemplo disso é a Lei Municipal de Campinas 8736/1996 que permite que $35 \%$ das áreas verdes públicas fiquem internas ao fechamento dos loteamentos.

Diante deste entendimento, e a fim de verificar a relação dos aglomerados intramuros na RMC com a preservação ambiental, foram feitas sobreposições dos mapas gerados nesta pesquisa com os mapas de áreas de interesse ambiental, disponibilizados pelo Instituto Florestal do Estado de São Paulo, com o intuito de mostrar visualmente a aproximação dos padrões residenciais murados com os meios físicos naturais. Para efeito ilustrativo, trazse ao presente estudo apenas os mapas dos municípios pertencentes ao maior eixo de concentração de aglomerados residenciais intramuros na RMC.

A capital da região metropolitana, por exemplo, possui três APAs, eixos verdes com propostas para parques lineares e alamedas verdes (Figura 15). É possível observar concentrações de aglomerados murados na APA Campinas e em alguns eixos verdes. O município de Paulínia, marcado por cursos d'água e APPs, apresenta também determinados padrões residenciais avizinhando-se, ou mesmo sobrepondo-se, em alguns pontos verdes (Figura 16).

Já nos municípios de Valinhos e Vinhedo, é possível observar que os aglomerados residenciais intramuros praticamente coexistem com áreas verdes e de proteção ambiental, conforme figuras 17 e 18 .

A título de estabelecer uma macrovisão da relação dos padrões residenciais com os diversos meios físicos naturais presentes na RMC, é possível analisar na Figura 19 que os Padrões 1 e 2 são os que mais ocupam ou fazem fronteira com áreas verdes, fato que pode ser explicado por estes serem também os padrões predominantes na RMC. Por sua vez, o Padrão 3 não apresentou nenhum intramuro dentro de áreas verdes, e os Padrões 4, 5 e 6 apresentam baixos índices de ocupação ou fronteira com áreas verdes, por também serem os que mais estão presentes dentro da malha urbana dos municípios (Figura 13), os quais se caracterizam comumente por terem menor porte e não interferirem no sistema viário da cidade.

Por fim, outra análise plausível obtida por meio da sobreposição de mapas diz respeito à concentração de intramuros em cada município da RMC. A Figura 20 mostra que o município de Campinas é o que mais possui aglomerações residenciais fechadas limítrofes ou ocupantes de áreas verdes, seguido de Paulínia, Valinhos e Vinhedo. Neste modo ilustrativo, também é possível perceber a distribuição de padrões que ocupam áreas de APA ou APP's em cada uma das cidades analisadas. As cidades não citadas no gráfico são as que não possuem exemplares dentro ou limítrofes a essas áreas.

Perante esses dados, observa-se que os padrões, embora planejados de modo a coexistirem com áreas verdes num mesmo empreendimento, perduram apesar de alguns municípios fixarem regras por meio de leis orgânicas, decretos municipais e gerenciamento de uso e ocupação do solo, com o objetivo de inibirem e amenizarem a ocupação urbana de suas áreas verdes protegidas. Desta forma, e ao menos em tese, faz-se mister o respeito às exigências de compatibilidade de projetos e ocupações de solo, condizentes com a Lei Federal 12.651 do Novo Código Florestal, a qual dispõe sobre a proteção da vegetação nativa.

Em Campinas, por exemplo, foi criada a Lei Municipal $\mathrm{n}^{\circ} 10.729 / 00$, a qual exige que novos loteamentos situados em APP's realizem e executem projetos de recuperação e/ou preservação ambiental desta área. Em adição, o Decreto Municipal n. ${ }^{\circ}$ 13.338/00, substituído pelo Decreto Municipal $\mathrm{n}$. 15.359/05, isenta a cobrança de Imposto Predial Territorial Urbano (IPTU) para áreas de APP's e/ou remanescentes vegetais, desde que seja comprovada a real preservação ambiental (Costa e Lessa, 2012). Já no município de Vinhedo, o Plano Diretor Participativo de 2007 estabeleceu para novas ocupações que o meio físico deveria ser o ordenador natural do território, e que os usos do solo deveriam respeitar os padrões 


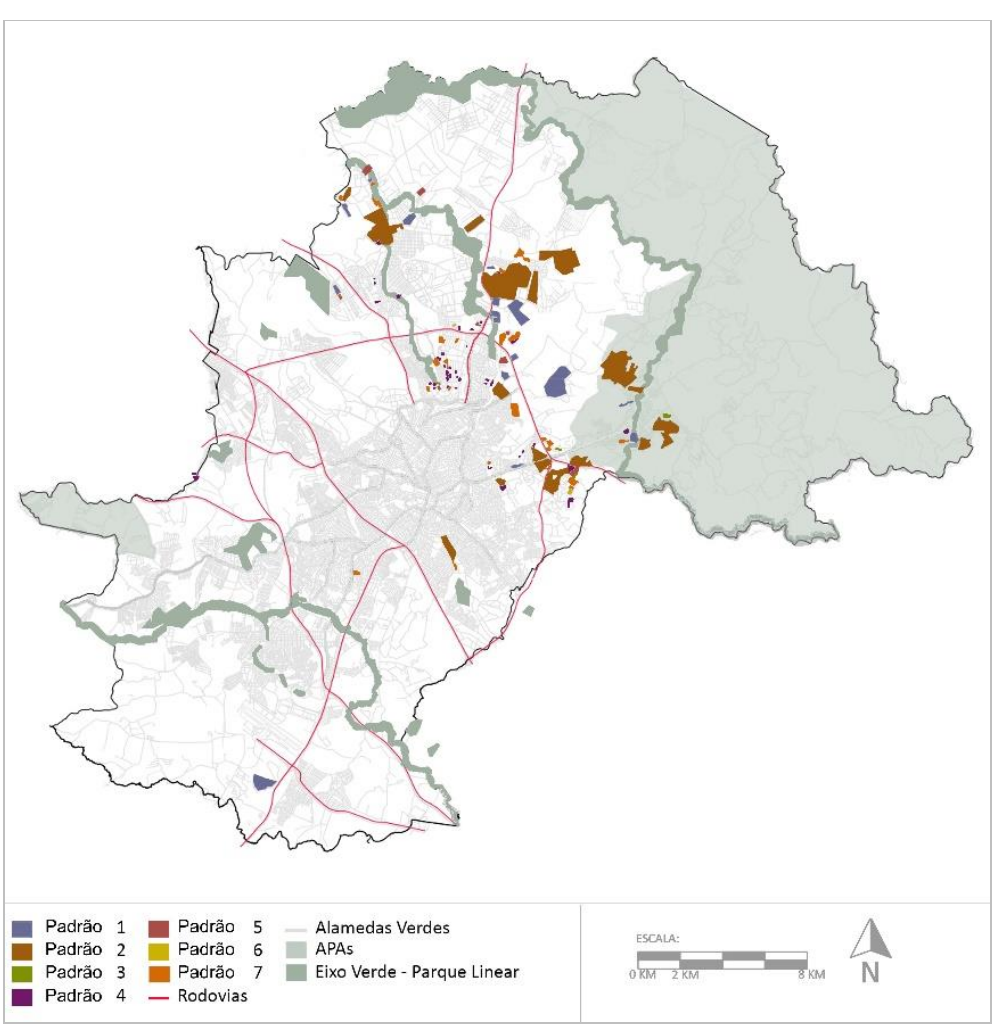

Figura 15. Áreas verdes em Campinas

(fonte: Autores, 2016, com base em mapa da Prefeitura Municipal de Campinas, 2015).

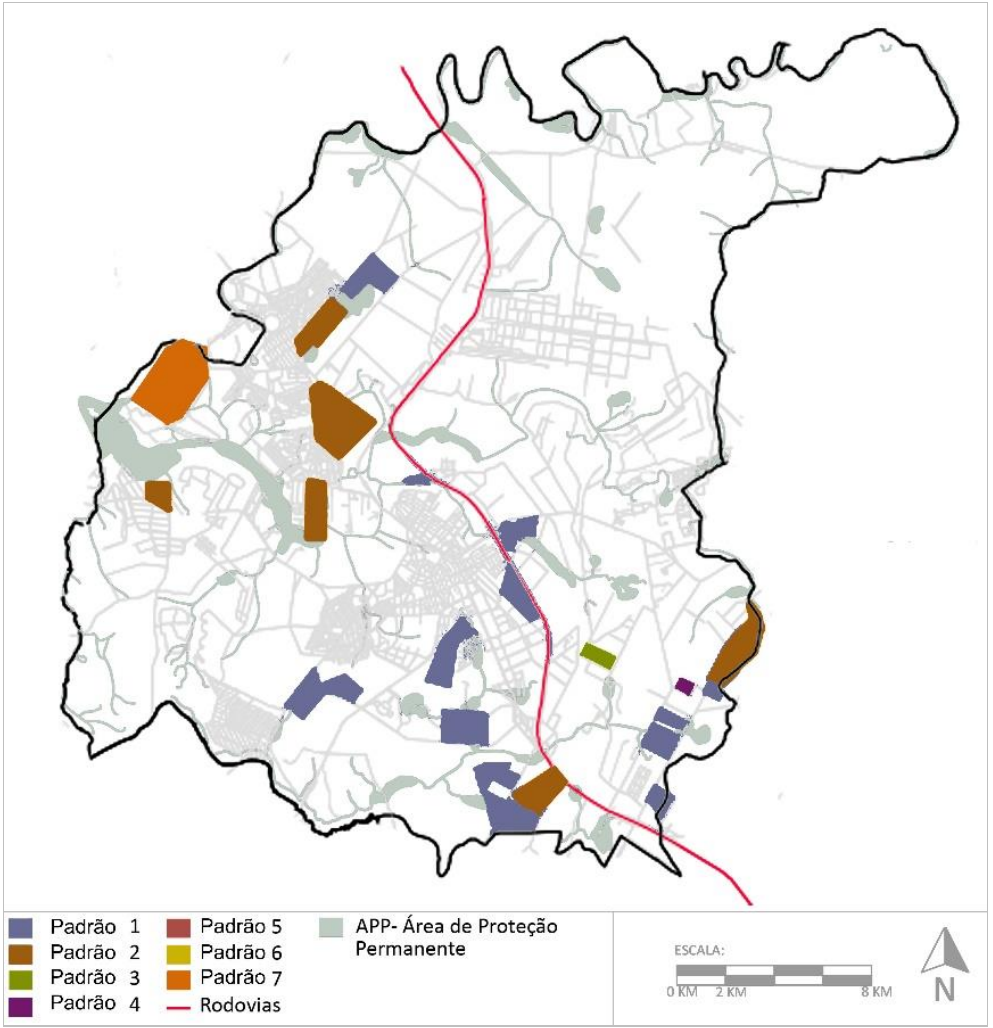

Figura 16. Áreas verdes em Paulínia

(fonte: Autores, 2016, com base em mapa de Campos, 2012). 


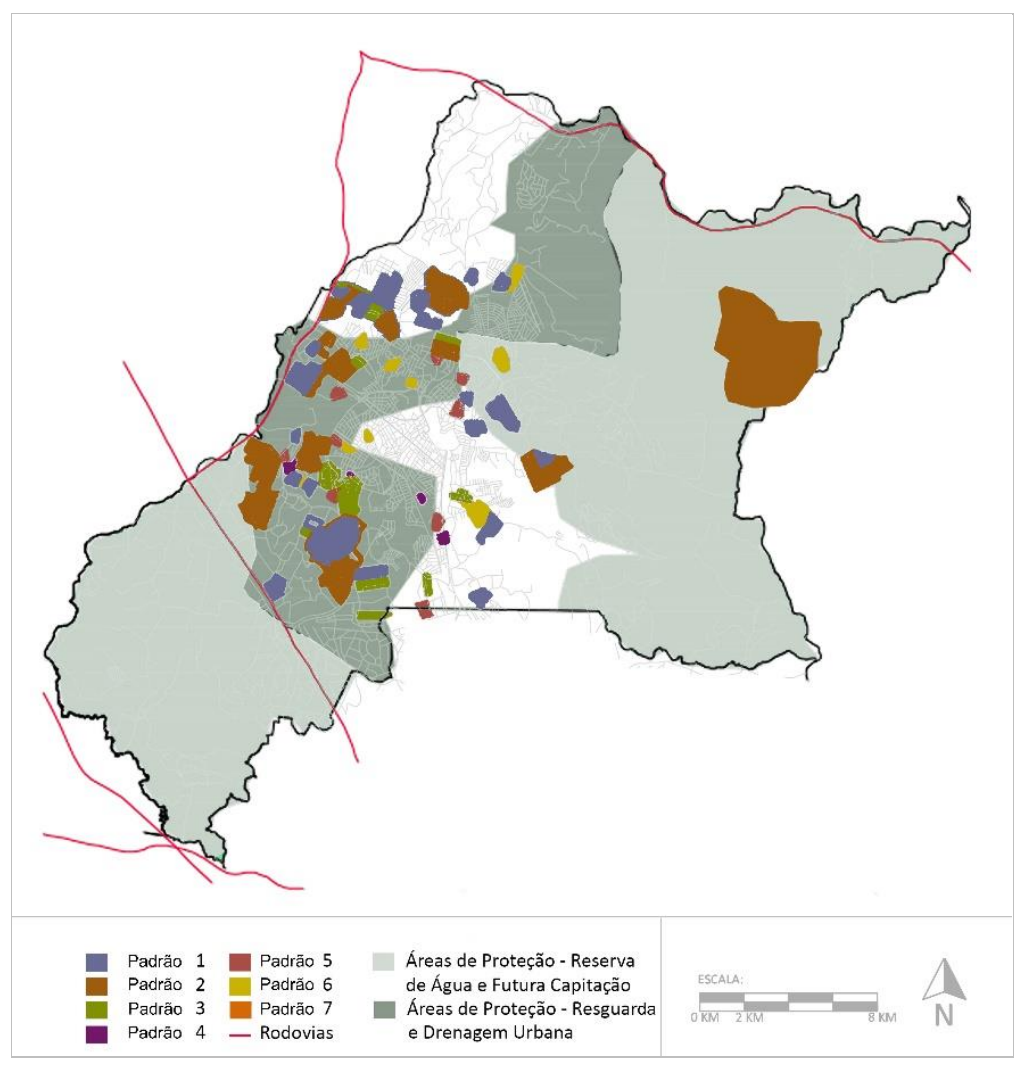

Figura 17. Áreas verdes em Valinhos

(fonte: Autores, 2016, com base em mapa da Prefeitura Municipal de Valinhos, 2009).

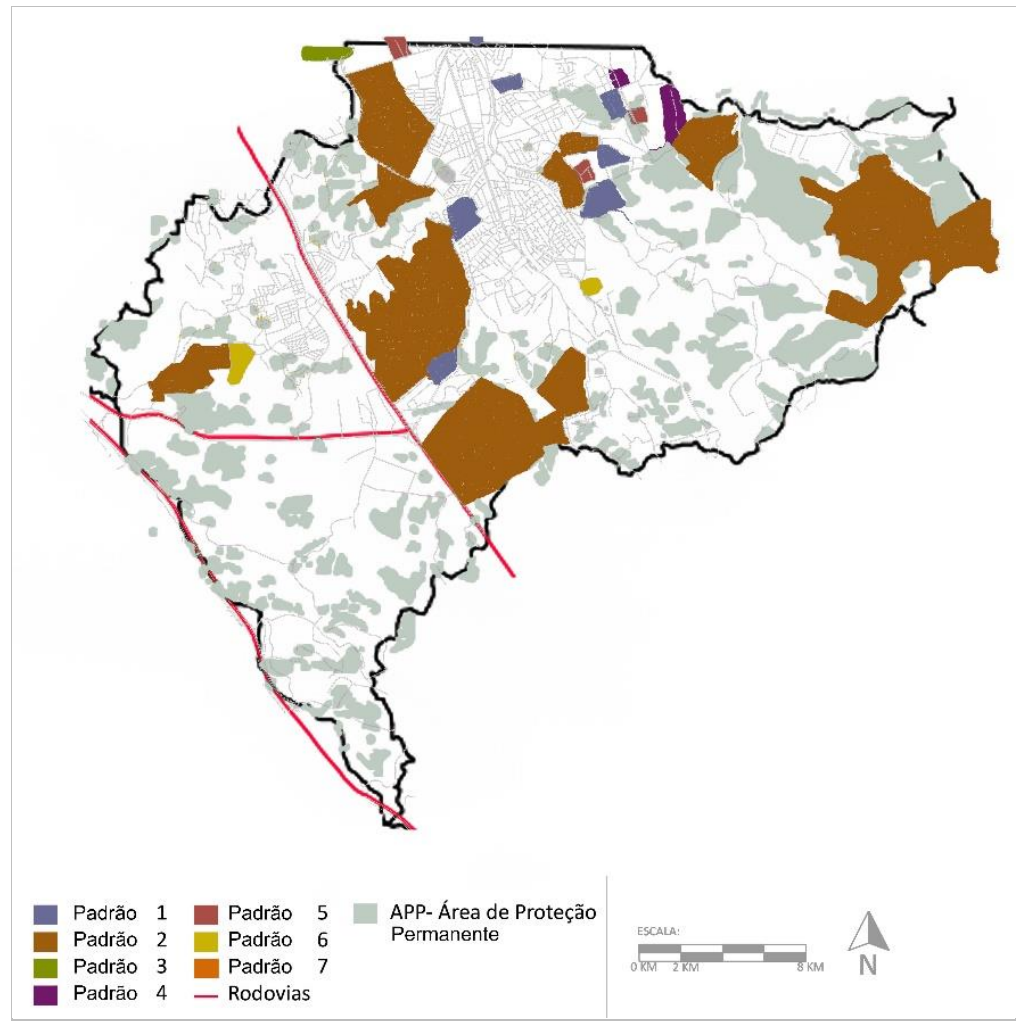

Figura 18. Áreas verdes em Vinhedo

(fonte: Autores, 2016, com base em mapa da Prefeitura Municipal de Vinhedo, 2016). 


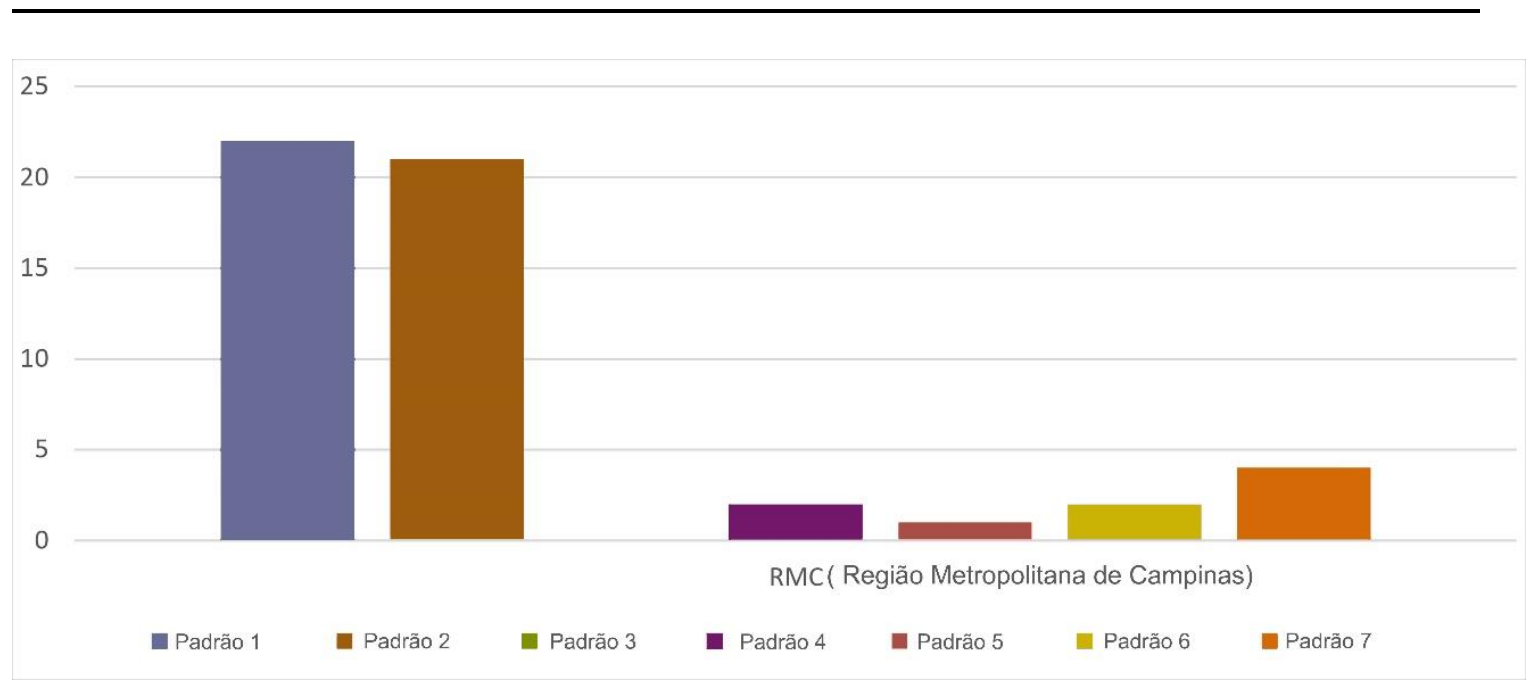

Figura 19. Padrões de intramuros que ocupam ou fazem fronteira com áreas verdes protegidas (fonte: Autores, com base em mapas municipais diversos).

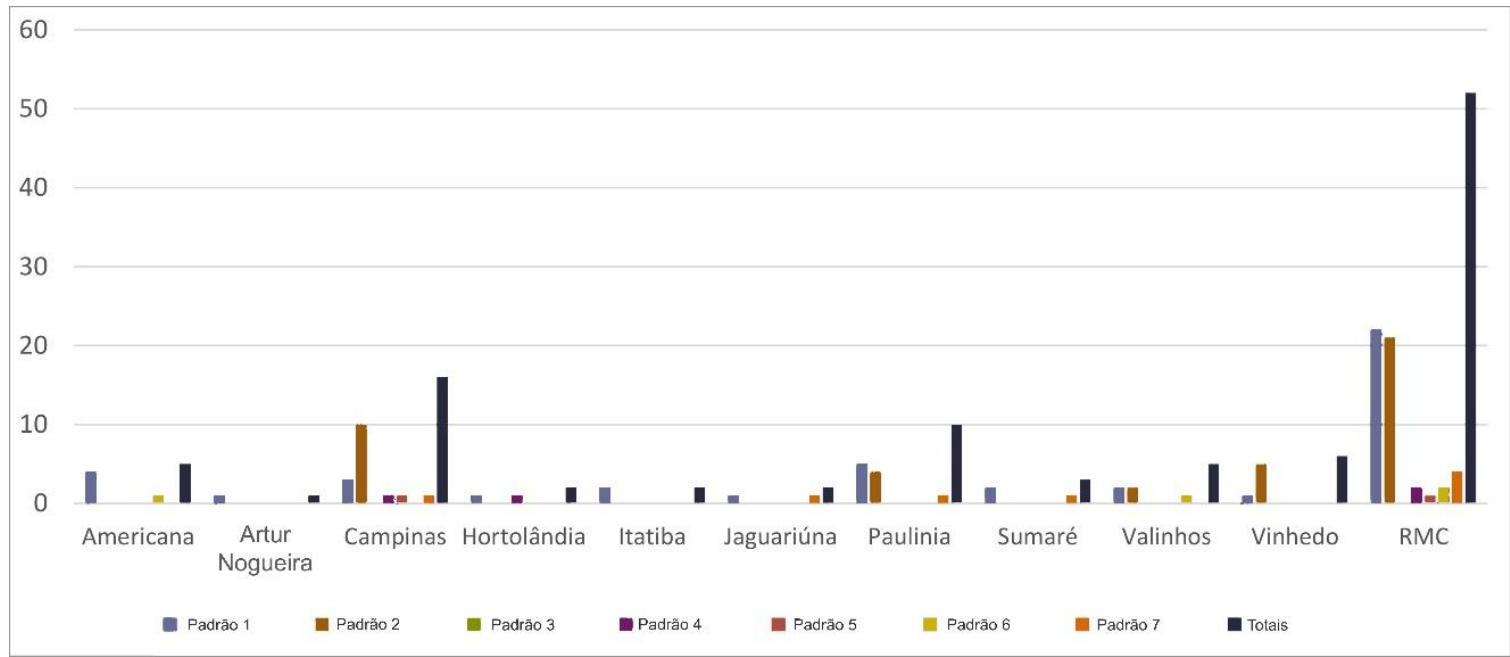

Figura 20. Quantidade de aglomerações residenciais horizontais muradas, definidas por padrões, que ocupam ou fazem fronteira com APAs ou APPs (fonte: Autores, com base em mapas municipais).

definidos nas diferentes macrozonas, as quais condicionam a ocupação das áreas ambientalmente frágeis considerando os parâmetros exigidos. Valinhos, por sua vez, embora não faça exigência de parecer ambiental prévio quando do projeto de empreendimentos residenciais intramuros, estabelece a avaliação do estudo de impacto da vizinhança e seu respectivo relatório por parte do órgão municipal competente; por meio deste relatório, o poder público, com base em análises ambientais e no próprio zoneamento, deverá fazer exigências necessárias ao empreendedor para a aplicação de medidas atenuadoras e compensatórias relativas aos impactos decorrentes da implantação da atividade (Costa e Lessa, 2012).

Não obstante, apesar das diretrizes ambientais estabelecidas, é notória a presença marcante dos residenciais horizontais intramuros nas ditas áreas de reserva e preservação ambiental, assim como aponta Costa e Lessa (2012), em um estudo realizado sobre condomínios e loteamentos fechados em parte dos municípios da RMC. 


\section{Conclusões}

Uma vez que o espaço urbano é composto por casas particulares, muros, vias, áreas verdes, dentre tantos outros elementos de forma urbana que compõem e estruturam a paisagem, o estudo de suas inter-relações contribuiu para o entendimento acerca das variações dos padrões de aglomerados intramuros no cenário urbano da Região Metropolitana de Campinas. Por meio da classificação dos residenciais, da caracterização de elementos particulares a cada um e da análise sobre a interação com o entorno, foi possível estabelecer relações destes aglomerados intramuros com os municípios da área recorte do estudo.

Neste sentido, a geolocalização de aglomerados residenciais intramuros na Região Metropolitana de Campinas, e seu posterior mapeamento, permitiu a identificação de variadas formas de ocupação destes exemplares habitacionais, bem como a classificação deles em 7 padrões diferentes, com características constantes, apesar de passível a variações. Dentre os sete, os padrões mais recorrentes na RMC são o 1 , em que o empreendimento nasce com o intuito de ser fechado e não considera em sua configuração a forma predominante do município; o 2, em que as aglomerações intramuros são de grande porte, mas seguem a forma da cidade; e o 4 , de pequeno porte, cuja configuração não interfere na forma predominante da cidade e o empreendimento é entregue com infraestrutura completa e habitações padronizadas. Dos 3 padrões dominantes, e de todos os sete recorrentes, somente o Padrão 4 respeita integralmente as normas legislativas federais. Os demais se consolidaram antes de normativas específicas ou ocorreram segundo adaptações de leis municipais.

Por meio de levantamentos gráficos, foi possível constatar que o número de residenciais fechados em cada município não representa uma comparação fiel à porcentagem do território municipal ocupado por estas modalidades habitacionais. Campinas, ao passo que possui o maior número de residenciais intramuros dentre a região metropolitana, dada a sua dimensão territorial, possui vasta percentagem desta modalidade habitacional em seu espaço urbano. A cidade de Vinhedo, por sua vez, é a que apresenta a maior porção do seu território ocupado por intramuros, seguida pelas cidades de Valinhos, Jaguariúna e Holambra.

O mapeamento dos residenciais intramuros também permitiu visualizar uma das suas premissas básicas de implantação, pois constatou-se que eles estão concentrados majoritariamente nas regiões periféricas das cidades, próximos às rodovias e vias arteriais, principalmente no eixo noroeste, centro e sudoeste da região metropolitana. Não obstante, possuem maior quantidade de exemplares em cidades que configuram a principal rota de ligação da RMC com a capital do Estado de São Paulo, como Paulínia, Campinas, Valinhos e Vinhedo. Em relação à interferência ambiental destes residenciais intramuros, foi possível observar que os condomínios regulamentados por lei federal são os que menos ocupam áreas verdes protegidas nas cidades. Já os padrões que conjugam exemplares de grande porte, fechados por decretos municipais, são os que mais ocupam ou fazem fronteira com áreas de preservação ambiental.

Após três décadas e meia de plena expansão, os residenciais intramuros se propagaram na RMC de forma oportuna e desmedida, a ponto de se ramificarem no mercado imobiliário para além das normas municipais e até mesmo federais. Os principais aspectos da natureza destes residenciais, contudo, se mostraram ainda presentes e constantes, no que diz respeito à proximidade a rodovias e áreas verdes. Foi a variedade deste produto que permitiu o desenvolvimento do presente artigo, o qual não pretende esgotar sua combinação de análises, mas sim abrir um leque de novas abordagens e questionamentos.

\section{Referências}

AGEMCAMP (2006) 'Estrutura Econômica da Região Metropolitana de Campinas', Relatório - Maio de 2006, São Paulo.

Baeninger, R. (2001) 'Região Metropolitana de Campinas: expansão e consolidação do urbano paulista', Migração e Ambiente nas Aglomerações Urbanas - Nepo/Unicamp, 321348. 
Correia, N. (2001) 'Paisagem habitacional e morfologia urbana - um estudo de caso em Pirituba', Tese de Mestrado não publicada, FAUUSP, Brasil.

Costa, A. K. e Lessa, S. N. (2012) 'Os Loteamentos Fechados na Região Metropolitana de Campinas: a apropriação da natureza e os serviços ambientais' VI Encontro Nacional da Anppas, Belém (http://www.anppas.org.br/encontro6/anais/AR QUIVOS/GT11-1306-108520120629142917.pdf) consultado em Agosto de 2015

Freitas, E. (2008) 'Loteamentos fechados' Tese de Doutorado não publicada, FAUUSP, Brasil.

Gonçalves Junior, F. e Correa, T. (2011) Entre rodovias: reflexões sobre a estruturação da paisagem urbana na Região Metropolitana de Campinas(http://observatoriogeograficoamerica latina.org.mx/egal14/Geografiasocioeconomica/ Geografiaurbana/073.pdf) consultado em Agosto de 2015.

IBGE (2014) 'Nota técnica: estimativas da população dos municípios brasileiros com data de referência em 1 de julho de 2014' (http://www.ibge.gov.br/home/presidencia/notici as/pdf/analise_estimativas_2014.pdf)consultado em Agosto de 2015.

IBGE (2010) 'Censo por Setores' (http:/www.censo2010.ibge.gov.br/sinopsepors etores/?nivel=st.) consultado em Agosto 2015.

Lamas, J. (1992) Morfologia urbana e desenho da cidade. (Fundação Calouste Gulbenkian Lisboa).

Melgaço, L. (2012) 'A cidade de poucos: condomínios fechados e a privatização do espaço público em Campinas' Boletim Campineiro de Geografia, 81-106.

Panerai, P. (2006) Tipologias. In: Análise urbana (Editora UnB, Brasília).

Prefeitura Municipal de Campinas (2015) 'Unidades de Conservação e Zonas de Amortecimento/Envoltórios'(http://www.campi nas.sp.gov.br/governo/meio-ambiente/conserva cao-da-natureza.php) consultado em Junho de 2017.

Prefeitura Municipal de Valinhos (2009). 'Zoneamento. Áreas de Proteção e Detalhes de Zoneamento em Áreas Isoladas' (http://www.valinhos.sp.gov.br/portal/arquivos/ planejamento/D_O_92_09__-_PDIII_-_ZONA S_ISOLADAS.pdf) consultado em Junho de 2017.

Prefeitura Municipal de Vinhedo (2007) 'Plano Diretor Participativo: Zonas de Interesse Ambiental' (http://www.vinhedo.sp.gov.br/pai nel/dbarquivos/dbanexos/1_zonasespeciaisinter esseambientalp.pdf) consultado em Junho de 2017.

Reis, N. (2006) Notas sobre urbanização dispersa e novas formas de tecido urbano (Via das Artes, São Paulo).

Silva, P. (2008) 'A expansão urbana de Campinas através de condomínios e loteamentos fechados (1974 - 2005)' Tese de Mestrado não publicada, Universidade de São Paulo, Brasil.

Vaz, L. (1994) 'Uma história da habitação coletiva na cidade do Rio de Janeiro' Tese de Doutorado não publicada,. FAUUSP, Brasil.

\title{
Tradução do título, resumo e palavras-chave
}

Morphological analysis of horizontal residential agglomerations within the Metropolitan Region of Campinas

\begin{abstract}
This paper analyses the horizontal gated communities in the Metropolitan Region of Campinas in the state of São Paulo. It evaluates the existing morphological patterns in the territory, quantifying their distribution among municipalities and reasoning about established interactions with main streets and green areas. It first contextualizes the origins of these communities from a legislative perspective. It then maps all closed housing agglomerations and describes their morphological patterns in terms of variations in size, characteristics of construction and of how they interfere in the street system and landscape. After this classification, it was possible to analyze, through maps and graphs, the distribution of these morphological patterns and their relationship with main streets and environmental preservation areas. The results reveal that, among the seven different patterns identified, it predominates the one characterized by constructions conceived with formal intention to set up private gated communities. Regarding the relationship between streets and green areas, the maps point out that most of these residential patterns occur in the peripheral areas of cities and along streets. In addition, it also reveals the presence of protected green areas inside gated communities, being the municipalities of Campinas, Paulínia, Valinhos and Vinhedo the largest examples of this phenomenon.
\end{abstract}

Keywords: Metropolitan Region of Campinas, gated allotments, gated communities, urban form, urban patterns 